\title{
Lanthanide Triple Helical Complexes with a Chiral Bis(benzimidazole)pyridine Derivative
}

\author{
Gilles Muller, ${ }^{[a, b]}$ James P. Riehl, ${ }^{[b]}$ Kurt J. Schenk, ${ }^{[c]}$ Gérard Hopfgartner, ${ }^{[\mathrm{d}]}$ Claude Piguet, ${ }^{[\mathrm{el}}$ \\ and Jean-Claude G. Bünzli*[a]
}

Keywords: Lanthanides / Tridentate ligands / Chirality / Luminescence / Stability constants

The ligand neopentyl 2,6-bis[(1-methylbenzimidazol-2-yl)]pyridine-4-carboxylate $\left(\mathbf{L}^{\mathbf{1 2}}\right)$ has been synthesised to test the effect of the chiral neopentyl ester group in the 4-position of the pyridine ring on (i) the helical wrapping, (ii) the diastereomeric induction and (iii) the thermodynamic and photophysical properties of the $\left[\operatorname{Ln}\left(\mathbf{L}^{\mathbf{1 2}}\right)_{3}\right]^{3+}$ complexes. The crystal structure of ligand $\mathbf{L}^{\mathbf{1 2}}$ shows the expected trans-trans conformation of the tridentate binding unit. The ligand forms stable 1:3 complexes in anhydrous acetonitrile $\left(\log \beta_{3}\right.$ in the range $17.3-19.0, \log K_{3}$ in the range $\left.2.9-4.6\right)$. The triple helical structure in solution is responsible for the four times larger specific rotary dispersion measured in the complexes. Circularly polarised luminescence of the Eu triple helical complex displays a weak effect, suggesting a small diastereomeric excess in solution. Ligand $\mathbf{L}^{\mathbf{1 2}}$ appears to favour a ${ }^{3} \pi \pi^{*}$-to-Ln energy transfer process for Eu, but temperaturedependent nonradiative processes lead to a very small quantum yield. High-resolution luminescence spectra indicate that the Eu complex has a distorted $D_{3}$ local symmetry at the metal ion site.

(C) Wiley-VCH Verlag GmbH, 69451 Weinheim, Germany, 2002)

\section{Introduction}

During the last two decades, lanthanide ions $\mathrm{Ln}^{\mathrm{III}}$ have proved to be powerful luminescent and magnetic probes in biology and medicine. ${ }^{[1-4]}$ In the latter field, applications range from diagnosis (e.g. fluoroimmunoasssays, ${ }^{[5-7]}$ luminescent specific imaging agents for tissues, ${ }^{\left[{ }^{8,9]}\right.}$ contrast agents for magnetic resonance imaging $\left.{ }^{[10]}\right)$ to therapeutic tools. ${ }^{[1]}$ In addition, these ions are also good catalysts for the selective hydrolysis of DNA and RNA. ${ }^{[12,13]}$

These applications require the introduction of the $\mathrm{Ln}^{\mathrm{III}}$ ions into functional molecular edifices able to preserve or better enhance the metal ion physicochemical properties. ${ }^{[14]}$ One strategy proposed to meet this goal is the formation of

[a] Institute of Molecular and Biological Chemistry, Swiss Federal Institute of Technology

BCH 1402 ,

1015 Lausanne, Switzerland

E-mail: jean-claude.bunzli@epfl.ch

[b] Department of Chemistry, University of Minnesota Duluth, Minnesota 55812-2496, USA

[c] Institute of Crystallography, BSP, University of Lausanne, 1015 Lausanne, Switzerland

[d] School of Pharmacy, University of Geneva, Switzerland,

30 quai E. Ansermet, 1211 Geneva 4, Switzerland

[e] Department of Inorganic, Analytical and Applied Chemistry, University of Geneva,

30 quai E. Ansermet, 1211 Geneva 4, Switzerland

Supporting information for this article is available on the WWW under http://www.ejic.com or from the author. induced cavities obtained by the self-assembly of carefully tailored multidentate ligands and podands. ${ }^{[15]} \mathrm{A}$ judicious design of the ligands results in weak noncovalent interstrand interactions stabilizing the molecular edifices. We have shown that tridentate aromatic ligands $\mathbf{L}^{\mathbf{1}}-\mathbf{L}^{\mathbf{9}}, \mathbf{L}^{\mathbf{1 1}}$ derived from bis(benzimidazole)pyridine (Scheme 1) lead to triple helical assemblies displaying sizeable $\pi \pi$-stacking interactions, whose structural, photophysical and thermodynamic properties can be tuned by varying the substituents $\mathrm{R}^{1}, \mathrm{R}^{2}$ and $\mathrm{R}^{3} \cdot{ }^{[16-18]}$ Substitution in the $\mathrm{R}^{2}$ position of the benzimidazole rings essentially controls the stability and the final structure of the complexes, while substitution in the $\mathrm{R}^{1}$ and $\mathrm{R}^{3}$ positions affects the electronic and photophysical properties.

So far, limited attention has been devoted to the inherent chirality of triple helical complexes, which often appear as racemic mixtures both in the solid state and in solution. However, Riehl et al. have shown that the $\left[\operatorname{Ln}(\mathrm{dpa})_{3}\right]^{3-}$ racemate equilibrium $\left(\mathrm{H}_{2} \mathrm{dpa}=\right.$ dipicolinic acid $)$ can be perturbed by adding chiral sugars. ${ }^{[19]}$ Moreover, a small excess of one enantiomer can be induced in the excited state with the use of circular polarised excitation light. ${ }^{[20]}$ Chiral lanthanide complexes are of potential great interest because of their use as probes for the sensing of chirality in biological substrates. ${ }^{[21,22]}$ Since the high lability of the $\mathrm{Ln}^{\mathrm{III}}$ ions favours easy racemisation of triple helical complexes, we are exploring the possibility of producing edifices in which the 


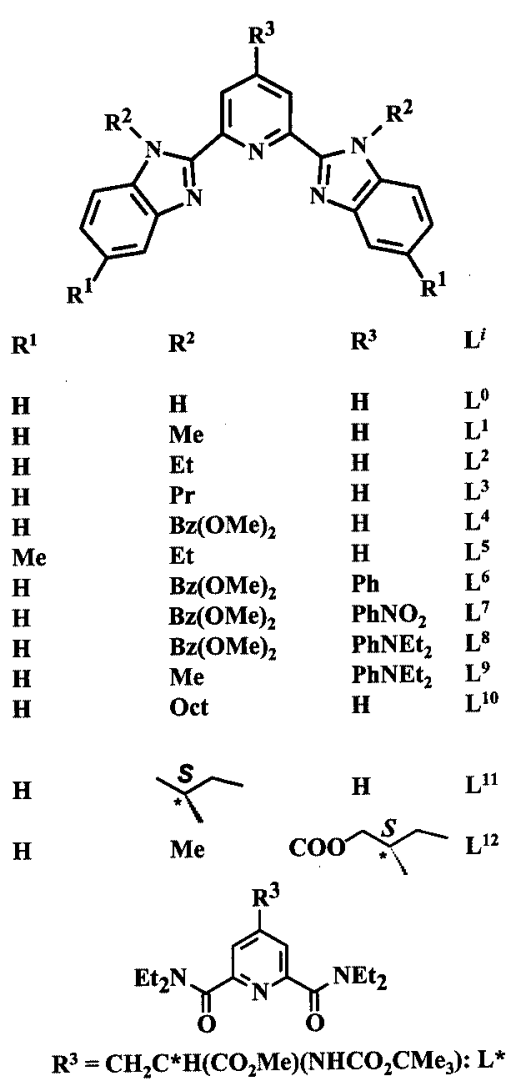

Scheme 1 chirality is brought about by the ligands, a method which can only be used if the diastereoisomers have a large enough energy difference.

Working along these lines, we have introduced a chiral substituent onto the benzimidazole side arms of bis(benzimidazole)pyridine to yield $\mathbf{L}^{\mathbf{1 1}}$. Unfortunately, the bulky neopentyl group precludes the formation of stable triple helical complexes. ${ }^{[18]}$ On the other hand, introducing a bulky chiral substituent in the 4-position $\left(\mathrm{R}^{3}\right)$ of a pyridine 2,6-dicarboxamide ( $\mathbf{L}^{*}$, Scheme 1) results in (i) helical wrapping of the three ligand strands around the $\mathrm{Ln}^{\mathrm{III}}$ ion, (ii) thermodynamically stable $1: 3$ complexes $\left(\log K_{3}\right.$ in acetonitrile is in the range 5.1-5.3), and (iii) a small excess of one diastereoisomer. ${ }^{[23]}$ To further our understanding of the influence of helical wrapping on diastereomeric induction, we introduce here a chiral neopentyl ester group in the pyridine $\mathrm{R}^{3}$ position of $\mathbf{L}^{\mathbf{1}}$ ( $\mathbf{L}^{\mathbf{1 2}}$, Scheme 1), and investigate its influence on the thermodynamic, chiro-optical and luminescent properties of the resulting tris complexes with $\mathrm{Ln}^{\mathrm{III}}$ ions.

\section{Results and Discussion}

\section{Synthesis and Characterisation of the Ligand and its Complexes}

Ligand $\mathbf{L}^{\mathbf{1 2}}$ was synthesised in a $48 \%$ yield from 2,6bis[(1-methylbenzimidazol-2-yl)]pyridine-4-carboxylic acid (6) by esterification with (-),(S)-2-methyl-1-butanol (Scheme 2), while 6 was initially obtained by a four-step

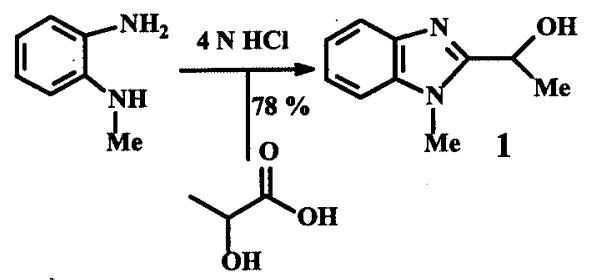

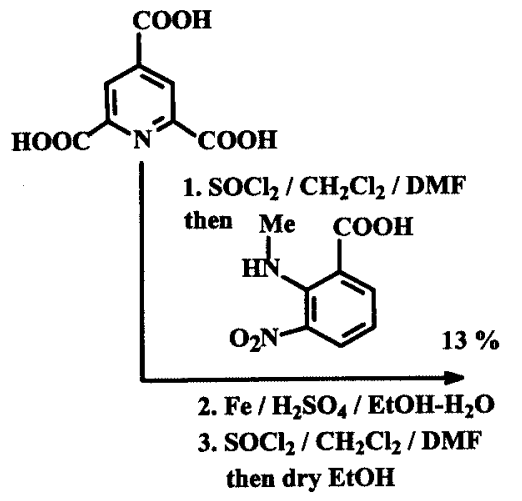

then dry EtOH

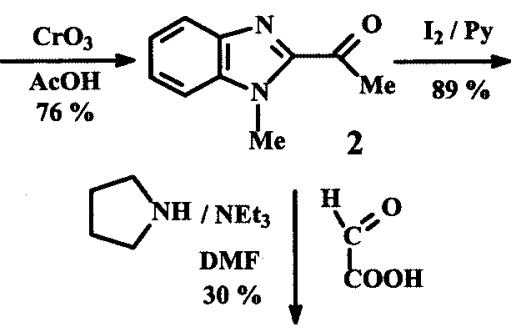<smiles>Cn1c(C(=O)C[n+]2ccccc2[I-])nc2ccccc21</smiles><smiles>Cn1c(C(=O)/C=C/C(=O)O)nc2ccccc21</smiles>

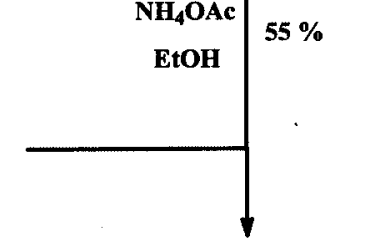<smiles>CCOC(=O)c1cc(-c2nc3ccccc3n2C)nc(-c2nc3ccccc3n2C(C)(C)S)c1</smiles><smiles>CC(C)O[Mg]O[Mg]</smiles><smiles>Cn1c(-c2cc(C(=O)O)cc(-c3nc4ccccc4n3C)n2)nc2ccccc21</smiles><smiles>CC[C@H](C)COC(=O)c1cc(-c2nc3ccccc3n2C)nc(-c2nc3ccccc3n2C(C)(C)C)c1</smiles>

$\mathbf{L}^{12}$

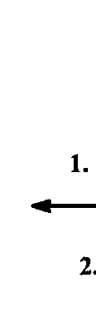


procedure involving a modified double Phillips coupling reaction to form the benzimidazole unit. ${ }^{[24]}$ Using an excess of $N$-ethyl-2-nitroaniline and 2,4,6-pyridinetricarboxylic acid favoured the formation of by-products such as the triamide, and significantly decreased the yield of the Phillips reaction. Consequently, we turned to a different strategy based on a procedure similar to that reported for the synthesis of $\mathbf{L}^{7}$ and $\mathbf{L}^{\mathbf{8}}{ }^{[25]}$ and made use of the Kröhnke reac$\operatorname{tion}^{[26]}$ for the construction of the 4-substituted central pyridine ring. The required pyridinium salt 3 was prepared by an Ortoleva-King reaction ${ }^{[27]}$ from 2-acetyl-1-methylbenzimidazole (2), while 4-(1-methylbenzimidazol-2-yl)-4-oxo-2butanoic acid (4) was obtained by a Knoevenagel condensation. ${ }^{[26,28]}$ Finally, $\mathbf{4}$ was synthesised by treating $\mathbf{2}$ with a mixture of glyoxylic acid monohydrate, triethylamine and pyrrolidine, which gave a better yield $(30 \%)$ and resulted in an easier isolation process than the originally proposed method based on UV-irradiation. ${ }^{[29]}$

The specific rotary dispersion of $\mathbf{L}^{\mathbf{1 2}}$ in degassed anhydrous acetonitrile, $[\alpha]_{\mathrm{D}}^{25}=8.1 \pm 0.4 \mathrm{deg} \mathrm{dm}^{2} \mathrm{~mol}^{-1}$, confirms the chirality arising from the asymmetric carbon atom. At room temperature, the ${ }^{1} \mathrm{H}$ and ${ }^{13} \mathrm{C}$ NMR spectra in $\mathrm{CDCl}_{3}$ $\left(5 \times 10^{-3} \mathrm{M}\right)$ display 13 and 17 signals, respectively, indicating a local pseudo twofold symmetry for the bis(benzimidazole)pyridine part of the molecule (Figure 1, Figure S1). These spectra coupled with $\left\{{ }^{1} \mathrm{H}-{ }^{1} \mathrm{H}\right\}$ COSY, DEPT-135, $\left\{{ }^{1} \mathrm{H}^{13} \mathrm{C}\right\}$ HSQC experiments and NOE effects observed between $\mathrm{H}^{4}$ and $\mathrm{N}-\mathrm{Me}$ (NOE effects do not exist between $\mathrm{H}^{5}$ and $\mathrm{N}-\mathrm{Me}$ ), clearly suggest that $\mathbf{L}^{\mathbf{1 2}}$ has a trans-trans conformation, similar to that observed in $\mathbf{L}^{\mathbf{1 1}}$. This conformation also prevails in the solid state, as demonstrated by the X-ray crystal structure (Table 1, Figure 2). The unit cell contains two independent molecules $\mathrm{A}$ and $\mathrm{B}$, the bond lengths and angles of which differ only slightly (Table S1). All aromatic groups are planar, but the benzimidazole units are not coplanar with the pyridine group, the interplanar angles being either very similar $\left(16.6^{\circ}\right.$ and $\left.10.9^{\circ}\right)$ or largely different $\left(36.3^{\circ}\right.$ and $\left.14.2^{\circ}\right)$ in molecules $\mathrm{A}$ and $\mathrm{B}$, respectively (Table S2). These angles result in an optimal packing coefficient. Finally, no noteworthy hydrogen-bonding or $\pi$ stacking interactions exist in the structure, which seems to be an example of a pure van der Waals packing.

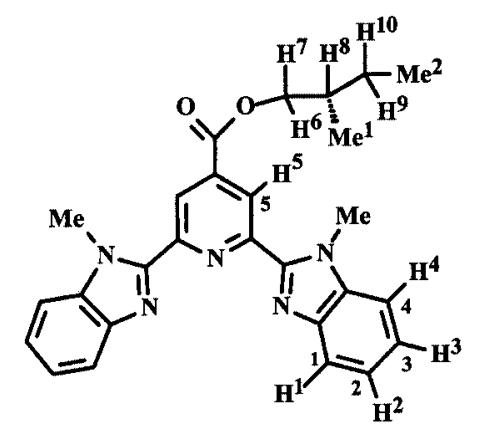

Figure 1. Numbering scheme for ligand $\mathbf{L}^{\mathbf{1 2}}$.
Table 1. Crystal data for $\mathbf{L}^{\mathbf{1 2}}$.

\begin{tabular}{ll}
\hline Formula & $\mathrm{C}_{27} \mathrm{H}_{27} \mathrm{~N}_{5} \mathrm{O}_{2}$ \\
$M$ & 453.54 \\
Crystal system & orthorhombic \\
Space group & $P 2_{1} 2_{1} 2_{1}$ \\
$a / \AA$ & $7.302(5)$ \\
$b / \AA$ & $16.582(5)$ \\
$c / \AA$ & $39.001(5)$ \\
$V / \AA^{3}$ & $4722(4)$ \\
$Z$ & 8 \\
$T / \mathrm{K}$ & $170(1)$ \\
$\mu\left(\right.$ Mo- $\left.K_{\alpha}\right) / \mathrm{mm}^{-1}$ & 0.083 \\
Reflections measured & 15587 \\
Independent reflections & $6273\left(R_{\text {int }}=0.1013\right)$ \\
Observed reflections $\left[F_{0} \geq 4 \sigma\left(F_{0}\right)\right]$ & 4529 \\
Final $R 1, w R 2[I>2 \sigma(I)]$ & $0.0743,0.1306$ \\
\hline
\end{tabular}

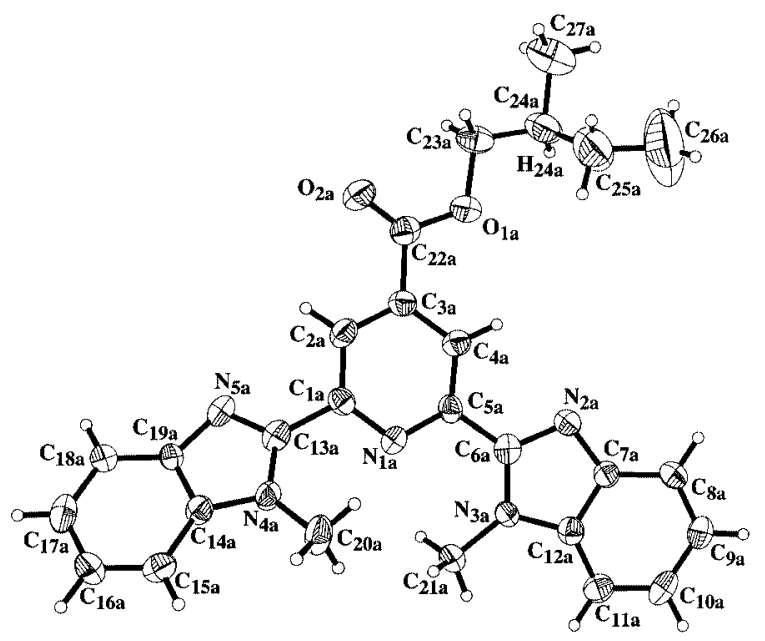

Figure 2. Molecular structure and atom numbering scheme for the two types of $\mathbf{L}^{\mathbf{1 2}}$ molecules found in the unit cell.

The 1:3 complexes were obtained in $70-80 \%$ yields, by adding a solution of $\mathbf{L}^{\mathbf{1 2}}$ in $\mathrm{CH}_{2} \mathrm{Cl}_{2}$ to solutions of lanthanide perchlorates in a mixture of $\mathrm{MeCN}$ and $\mathrm{CH}_{2} \mathrm{Cl}_{2}$. Evidence for complexation is the blue shift of the $v_{\mathrm{CO}}$ and the two $v_{\mathrm{C}=\mathrm{C}}$ pyridine and benzimidazole vibrations by $4-6$ $\mathrm{cm}^{-1}$ and $2-6 \mathrm{~cm}^{-1}$, respectively. All perchlorate ions are ionic; hence the complexes are most probably nine-coordinate (see below). Single crystals for X-ray structure determination could not be obtained.

\section{Interactions between $\mathrm{L}^{12}$ and the $\mathrm{Ln}^{\mathrm{III}}$ Ions}

The various species in solution were first identified by ESI-MS. Solutions of $\mathbf{L}^{\mathbf{1 2}}\left(10^{-4} \mathrm{M}\right.$ in anhydrous acetonitrile) were titrated with $\mathrm{Ln}\left(\mathrm{ClO}_{4}\right)_{3} \cdot x \mathrm{H}_{2} \mathrm{O}(x=0.2-0.6)$ at $298 \mathrm{~K}$, for ratios $R=\left[\mathbf{L}^{12}\right]_{t} /\left[\mathrm{Ln}^{\mathrm{III}}\right]_{t}=0-3$. The spectra clearly show the successive formation of $1: n(n=1-4)$ species, some of which had solvation molecules and/or were in the 
Table 2. Relative intensities of the ESIMS peaks for solutions with $\left[\mathbf{L}^{\mathbf{1 2}}\right]_{t} /\left[\mathrm{Ln}^{\mathrm{III}}\right]_{t}=3(\mathrm{MeCN}, 298 \mathrm{~K})$

\begin{tabular}{lccc}
\hline Species & $\mathrm{La}$ & $\mathrm{Eu}$ & $\mathrm{Lu}$ \\
\hline$\left[\operatorname{Ln}\left(\mathbf{L}^{\mathbf{1 2}}\right)_{3}\right]^{3+}$ & 100 & 100 & 0.0 \\
{$\left[\mathrm{Ln}\left(\mathbf{L}^{\mathbf{1 2}}\right)_{4}\right]^{3+}$} & 16.7 & 17.8 & 0.0 \\
{$\left[\mathrm{Ln}\left(\mathbf{L}^{\mathbf{2}}\right)_{2}\left(\mathrm{ClO}_{4}\right)\right]^{2+}$} & 7.5 & 9.2 & 0.0 \\
{$\left[\mathrm{Ln}\left(\mathbf{L}^{\mathbf{1 2}}\right)_{3}\left(\mathrm{ClO}_{4}\right)\right]^{2+}$} & 12.5 & 0.0 & 0.0 \\
{$\left[\mathrm{Ln}\left(\mathbf{L}^{\mathbf{1 2}}\right)_{3}(\mathrm{MeCN})_{4}\right]^{3+}$} & 0.0 & 0.0 & 100 \\
{$\left[\operatorname{Ln}\left(\mathbf{L}^{\mathbf{1 2}}\right)_{2}(\mathrm{MeCN})\right]^{3+}$} & 0.0 & 0.0 & 75 \\
\hline
\end{tabular}

form of perchlorate adducts (Table 2, Table S3). For La and $\mathrm{Eu}$, the 1:3 complex $(R=3)$ is most abundant, while for $\mathrm{Lu}$, this species coexists in solution with the 1:2 complex. In parallel, the proportion of the $\left[\operatorname{Ln}\left(\mathbf{L}^{\mathbf{1 2}}\right)_{4}\right]^{3+}$ species is relatively important for the larger ions $(\mathrm{La}, \mathrm{Eu})$, but this species is not seen for Lu. Such complexes have been observed for ligands derived from pyridine 2,6-dicarboxamide and were assigned to an outer-sphere association of a fourth ligand with a 1:3 complex. ${ }^{[23,30]}$ The ES-MS data clearly point to the presence of stable 1:3 complexes with $\mathrm{La}$ and $\mathrm{Eu}$, while the formation of this species with $\mathrm{Lu}$ appears to be less favoured.

To confirm the speciation, the titration of $\mathbf{L}^{\mathbf{1 2}}\left(10^{-3} \mathrm{M}\right.$ in $\mathrm{CD}_{3} \mathrm{CN}$ ) with $\mathrm{La}^{\mathrm{III}}$ and $\mathrm{Lu}^{\mathrm{III}}$ ions has been monitored by $400 \mathrm{MHz}{ }^{1} \mathrm{H}$ NMR spectroscopy. Chemical shifts are reported in Table 3, while Figure S2 (see Supporting Information) presents the aromatic part of the spectra obtained with Lu. Signals for the 1:1, 1:2, and 1:3 complexes could clearly be identified for both ions. When $R$ reaches 3 , the tris species is the major complex in solution for $\mathrm{La}(>68 \%)$ and $\mathrm{Lu}(50 \%)$; the other species in solution is the 1:2 complex. This observation confirms that the bulky neopentyl ester group increases the steric constraint in the triple helical complexes with the smaller lanthanide ions. The stability constants extracted from ${ }^{1} \mathrm{H}$ NMR spectroscopic data and analysed with MINEQL $^{+}{ }^{[31]}$ are reported in Table 4. The apparent ease with which the 1:3 complex forms contrasts with the situation observed with $\mathbf{L}^{\mathbf{1 1}}$, and indicates that the substitution in the $\mathrm{R}^{3}$ position of the central pyridine is less detrimental to the formation of the helical complexes compared with substitution on the benzimidazole rings. ${ }^{[18]}$
Table 4. Stability constants of $\left[\operatorname{Ln}\left(\mathbf{L}^{\mathbf{1 2}}\right)_{n}\right]^{3+}$ complexes $(n=1-3)$ as determined by NMR spectroscopy and UV/Vis spectrometry $\left(\mu=0.1 \mathrm{M} \mathrm{Et}_{4} \mathrm{NClO}_{4}, 298 \mathrm{~K}, \pm 2 \sigma\right)$

\begin{tabular}{lllllll}
\hline & \multicolumn{3}{c}{$\log K_{1}$} & \multicolumn{2}{c}{$\log K_{2}$} & \multicolumn{2}{c}{$\log K_{3}$} \\
Ln & UV/Vis & NMR & UV/Vis & NMR & UV/Vis ${ }^{[\mathrm{a}]}$ & NMR \\
\hline $\mathrm{La}$ & $7.8 \pm 0.4$ & $8.0 \pm 0.2$ & $6.0 \pm 0.5$ & $6.0 \pm 0.3$ & $3.8 \pm 0.6$ & \multirow{2}{*}{$3.8 \pm 0.3$} \\
$\mathrm{Eu}$ & $8.0 \pm 0.3$ & {$[\mathrm{~b}]$} & $6.4 \pm 0.4$ & {$[\mathrm{~b}]$} & $4.6 \pm 0.5$ & {$[\mathrm{~b}]$} \\
$\mathrm{Lu}$ & $8.0 \pm 0.3$ & $7.9 \pm 0.2$ & $6.4 \pm 0.4$ & $6.5 \pm 0.3$ & $2.9 \pm 0.4$ & $3.1 \pm 0.3$ \\
\hline [a] Values of $\log K_{1}$ and $\log K_{2}$ were fixed. ${ }^{[\mathrm{b}]}$ Not determined.
\end{tabular}

To quantify the $\mathrm{Ln}^{\mathrm{III}}-\mathbf{L}^{\mathbf{1 2}}$ interaction further, we have performed spectrophotometric titrations of $\mathbf{L}^{\mathbf{1 2}}$ with $\mathrm{Ln}(\mathrm{Otf})_{3}(\mathrm{Ln}=\mathrm{La}, \mathrm{Eu}, \mathrm{Lu}$; Otf $=$ trifluoromethanesulfonate) at $298 \mathrm{~K}$ in $\mathrm{MeCN}$, in the presence of $0.1 \mathrm{M} \mathrm{Et}_{4} \mathrm{NClO}_{4}$, under anhydrous conditions $\left(\left[\mathrm{H}_{2} \mathrm{O}\right]<30 \mathrm{ppm}\right)$. Factor analysis $^{[32]}$ indicates the presence of three or four absorbing species and the data can be fitted to Equations (1)-(3), where solvation and anion coordination has been omitted.

$\mathrm{Ln}^{3+}+\mathbf{L}^{\mathbf{1 2}} \underset{\leftarrow}{\rightleftarrows}\left[\operatorname{Ln}\left(\mathbf{L}^{\mathbf{1 2}}\right)\right]^{3+} \log \beta_{1}$

$\mathrm{Ln}^{3+}+2 \mathbf{L}^{\mathbf{1 2}} \underset{\leftarrow}{\rightleftarrows}\left[\mathrm{Ln}\left(\mathbf{L}^{\mathbf{1 2}}\right)_{2}\right]^{3+} \log \beta_{2}$

$\mathrm{Ln}^{3+}+3 \mathbf{L}^{\mathbf{1 2}} \underset{\leftarrow}{\rightleftarrows}\left[\operatorname{Ln}\left(\mathbf{L}^{\mathbf{1 2}}\right)_{3}\right]^{3+} \log \beta_{3}$

A model including $\left[\operatorname{Ln}\left(\mathbf{L}^{\mathbf{1 2}}\right)_{4}\right]^{3+}$ does not improve the fit, in agreement with the postulated outer-sphere nature of this species detected in the gas phase. Electronic spectra of the three complexes are correlated, which renders the fitting process difficult and generates relatively large uncertainties in the $\log \beta_{i}$ values (Table 4 ). The stability constants are in a good agreement with those extracted from NMR spectroscopic data. The interactions between $\mathbf{L}^{\mathbf{1 2}}$ and the $\mathrm{Ln}^{\mathrm{III}}$ ions are stronger than those with $\mathbf{L}^{\mathbf{1 1}}$, as indicated by $\Delta \log K_{3}\left(\mathbf{L}^{\mathbf{1 2}}-\mathbf{L}^{\mathbf{1 1}}\right)=2.6$ and 3.7 for $\mathrm{La}$ and $\mathrm{Eu}$, respectively. ${ }^{[18]}$ According to previous studies with ligands derived from bis(benzimidazole)pyridine, ${ }^{[17]}$ the methyl substituents bound to the benzimidazole side arms in $\mathbf{L}^{\mathbf{1 2}}$ favour the formation of a tight cavity around the lanthanide ions. This is not the case for the neopentyl groups in $\mathbf{L}^{\mathbf{1 1}}$. This observation also confirms the large influence of the alkyl $N$-substituents on the formation of the 1:3 complexes. However, the size-discriminating effect along the lanthanide series, and the stability of the $\left[\operatorname{Ln}\left(\mathbf{L}^{i}\right)_{3}\right]^{3+}$ complexes, are largely influenced by the substituents on the benzimidazole and

Table 3. ${ }^{1} \mathrm{H}$ NMR shifts observed (ppm) for $\mathbf{L}^{\mathbf{1 2}}$ in $\mathrm{CDCl}_{3}$ and for its $1: 1,1: 2$, and 1:3 complexes with $\mathrm{Ln}^{\mathrm{III}}$ ions in $\mathrm{CD}_{3} \mathrm{CN}\left(10^{-3}\right.$ M, 298 K).

\begin{tabular}{|c|c|c|c|c|c|c|c|c|c|c|c|}
\hline Species & $\mathrm{H}^{1}$ & $\mathrm{H}^{2}$ & $\mathrm{H}^{3}$ & $\mathrm{H}^{4}$ & $\mathrm{H}^{5}$ & $\mathrm{H}^{6,7}$ & $\mathrm{H}^{8}$ & $\mathrm{H}^{9,10}$ & $\mathrm{Me}$ & $\mathrm{Me}^{1}$ & $\mathrm{Me}^{2}$ \\
\hline $\mathrm{L}^{12}$ & 7.90 & \multicolumn{2}{|c|}{$7.32-7.43$} & 7.48 & 8.92 & $4.23,4.32$ & 1.95 & $1.29,1.56$ & 4.24 & 1.04 & 0.97 \\
\hline La $1: 1$ & 8.31 & \multicolumn{2}{|c|}{$7.56-7.65$} & 7.81 & 8.78 & $4.36,4.41$ & 1.96 & $1.39,1.62$ & 4.32 & 1.10 & 1.02 \\
\hline La $1: 2$ & 7.59 & 7.28 & 6.91 & 7.20 & 8.87 & $4.40,4.46$ & 2.03 & $1.44,1.66$ & 4.34 & 1.14 & 1.05 \\
\hline La $1: 3$ & 7.74 & 7.35 & 6.83 & 7.16 & 8.03 & $4.31,4.35$ & 1.92 & $1.37,1.56$ & 3.82 & 1.07 & 1.02 \\
\hline $\mathrm{Lu} 1: 1$ & 8.12 & 7.67 & 7.63 & 7.87 & 8.91 & $4.39,4.44$ & 2.04 & $1.46,1.52$ & 4.41 & 1.12 & 1.03 \\
\hline Lu 1:2 & 7.56 & 7.34 & 7.09 & 6.98 & 9.00 & $4.45,4.52$ & 2.06 & $1.45,1.68$ & 4.24 & 1.17 & 1.07 \\
\hline Lu 1:3 & 7.82 & 7.43 & 7.49 & 7.68 & 8.81 & $4.25,4.30$ & 1.94 & $1.35,1.58$ & 4.28 & 1.06 & 0.99 \\
\hline
\end{tabular}


central pyridine groups; the latter acting on the electron density of the pyridyl $\mathrm{N}$ atom. The introduction of an electron-attracting neopentyl ester group in $\mathbf{L}^{\mathbf{1 2}}$ decreases the electronic density on the pyridyl $\mathrm{N}$ atom, which reduces the electrostatic interaction, as indicated by $\Delta \log K_{3}\left(\mathbf{L}^{\mathbf{1}}-\mathbf{L}^{\mathbf{2}}\right)=$ $1.0-1.1$, but the size-discriminating effect is retained. ${ }^{[17]}$

The specific rotary dispersion of solutions of the $\left[\operatorname{Ln}\left(\mathbf{L}^{\mathbf{1 2}}\right)_{3}\right]^{3+}$ complexes $\left(10^{-3} \mathrm{M}\right.$ in anhydrous acetonitrile) is $33.5 \pm 0.5(\mathrm{La})$ and $31.0 \pm 0.3 \mathrm{deg} \mathrm{dm}^{2} \mathrm{~mol}^{-1}(\mathrm{Eu})$. This is about four times larger than those measured for the free ligand. We assign the greater rotary dispersion with respect to that generated by three free ligands to a structural contribution such as the formation of triple helical complexes in solution, as observed for $\mathbf{L}^{*}{ }^{[23]}$ As a comparison, relatively little or no $\left(4-5 \mathrm{deg} \mathrm{dm}^{2} \mathrm{~mol}^{-1}\right)$ structural contribution was observed for the 1:1 and 1:2 complexes with $\mathbf{L}^{11}{ }^{118]}$ The circularly polarised luminescence (CPL) spectrum of a $5 \times 10^{-3} \mathrm{M}$ solution of $\left[\mathrm{Eu}\left(\mathbf{L}^{\mathbf{1 2}}\right)_{3}\right]^{3+}$ is plotted in Figure 3 in the spectral range of the ${ }^{5} \mathrm{D}_{0} \rightarrow{ }^{7} \mathrm{~F}_{1}$ transition,

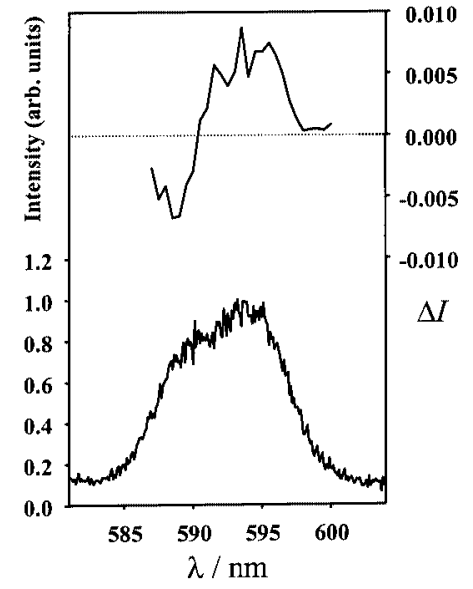

Figure 3. CPL spectrum of the ${ }^{5} \mathrm{D}_{0} \rightarrow{ }^{7} \mathrm{~F}_{1}$ transition of $\left[\mathrm{Eu}\left(\mathbf{L}^{\mathbf{1 2}}\right)_{3}\right]^{3+}$ $\left(5 \times 10^{-3} \mathrm{M}\right.$ in anhydrous $\mathrm{MeCN}$ at $\left.295 \mathrm{~K}\right)$, on ligand excitation at $386 \mathrm{~nm}$. which is particularly well-suited for CPL measurements since it satisfies the magnetic-dipole selection rule, $\Delta J=0$, \pm 1 . The spectrum depends on the polarisation of the excitation light, indicating the presence of two species in solution. ${ }^{[33]}$ At the concentrations used, $93 \%$ of the $\mathrm{Eu}^{\mathrm{III}}$ ion is in the form of the 1:3 complex, and $7 \%$ in the form of the 1:2 species, which is expected to generate a smaller chiral effect. The second species could also be a complex in which partial decomplexation of a ligand strand is induced by the interaction with one water molecule (see below). In conclusion, the CPL data are consistent with the presence of a small excess of one diastereoisomer in solution, on the short time scale of optical measurements, as previously observed for the corresponding complex with $\mathbf{L}^{*}$. ${ }^{[23]}$

\section{Photophysical Properties}

The electronic spectrum of $\mathbf{L}^{\mathbf{1 2}}$ in $\mathrm{MeCN}$ displays two intense bands centred around 33950 and $29590 \mathrm{~cm}^{-1}$, with a shoulder at higher energy (Table 5, Figure 4). Irradiation in the UV region at room temperature yields one broad unresolved fluorescence band, centred around $22885 \mathrm{~cm}^{-1}$ and originating from the ${ }^{1} \pi \pi^{*}$ level (Figure 5 ). At $77 \mathrm{~K}$, the fluorescence band is more structured and emission from the

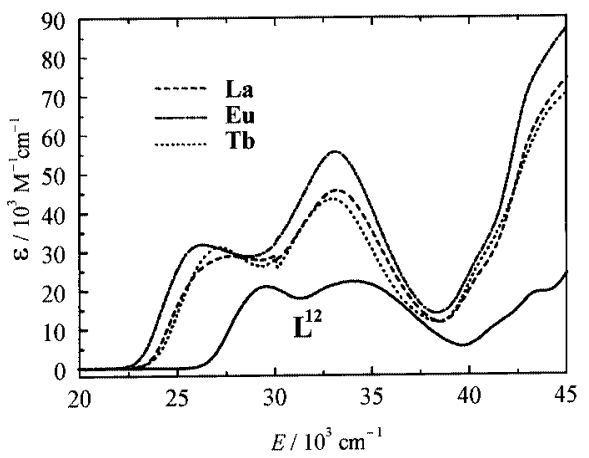

Figure 4. UV/Vis spectra of $\mathbf{L}^{\mathbf{1 2}}$ and its $\left[\operatorname{Ln}\left(\mathbf{L}^{\mathbf{1 2}}\right)_{3}\right]^{3+}$ complexes $\left(10^{-3} \mathrm{M}\right.$ in anhydrous $\mathrm{MeCN}$ at $\left.293 \mathrm{~K}\right)$.

Table 5. Ligand-centred absorptions in acetonitrile and in the solid state $(293 \mathrm{~K})$, ligand-centred singlet- and triplet-state energies as determined from the emission spectra of the solids $(77 \mathrm{~K})$ and of the solutions $\left(10^{-3} \mathbf{M}\right.$ in acetonitrile at $\left.293 \mathrm{~K}\right)$ for the ligand $\mathbf{L}^{\mathbf{1 2}}$ and its triple helical complexes $\left[\operatorname{Ln}\left(\mathbf{L}^{\mathbf{1 2}}\right)_{3}\right]^{3+}$.

\begin{tabular}{|c|c|c|c|c|c|}
\hline Compnd & $\begin{array}{l}E\left(x \rightarrow \pi^{*}\right) / \mathrm{cm}^{-1[\mathrm{a}]} \\
\text { Solution }^{[\mathrm{b}]}\end{array}$ & solid state & $\begin{array}{l}E\left({ }^{1} \pi \pi^{*}\right) / \mathrm{cm}^{-1} \\
\text { solution }\end{array}$ & solid state ${ }^{[\mathrm{c}]}$ & $E\left({ }^{3} \pi \pi^{*}\right) / \mathrm{cm}^{-1}$ solid state ${ }^{[\mathrm{c}]}$ \\
\hline \multirow[t]{3}{*}{$\mathrm{L}^{12}$} & $43480(4.28) \mathrm{sh}^{[\mathrm{d}]}$ & $43480 \mathrm{sh}$ & & & \\
\hline & $33950(4.35)$ & 33670 & & 23570 & 20920 \\
\hline & $29590(4.32)$ & 27100 & 22885 & 22960 & 17670 \\
\hline \multirow[t]{3}{*}[\mathrm{La}(\mathbf{L}^{\mathbf{12}})_{3}]{$^{3+}$} & $42980(4.76) \mathrm{sh}$ & $45660 \mathrm{sh}$ & & & \\
\hline & $33220(4.66) 27630(4.46)$ & 34485 & & 22100 & 19750 \\
\hline & & 24940 & 21210 & 22350 & 17990 \\
\hline \multirow[t]{2}{*}[\mathrm{Eu}(\mathbf{L}^{\mathbf{12}})_{3}]{$^{3+}$} & $43670(4.89) \mathrm{sh}$ & $41490 \mathrm{sh}$ & & & \\
\hline & $33115(4.74) 26255(4.50)$ & $\begin{array}{l}35715 \\
24215\end{array}$ & 21100 & [e] & [e] \\
\hline \multirow[t]{2}{*}[\mathrm{Tb}(\mathbf{L}^{\mathbf{12}})_{3}]{$^{3+}$} & 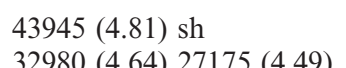 & $39215 \mathrm{sh}$ & & & \\
\hline & & 24450 & 21645 & 22475 & 21050 \\
\hline
\end{tabular}

${ }^{[\mathrm{a}]} x=\mathrm{n}$ or $\pi{ }^{[\mathrm{b}]}$ At the concentration used, $67-85 \%$ of the metal ion is in the form of the $1: 3$ complex and $15-33 \%$ in the form of the 1:2 complex; $\log \varepsilon$ values are given in parentheses. ${ }^{[c]}$ The 0 -phonon transition is given in italics for frozen solutions in acetonitrile. [d] $\mathrm{sh}=$ shoulder. ${ }^{[\mathrm{e}]}$ not observed because of the L12-to-Ln energy transfer process. 

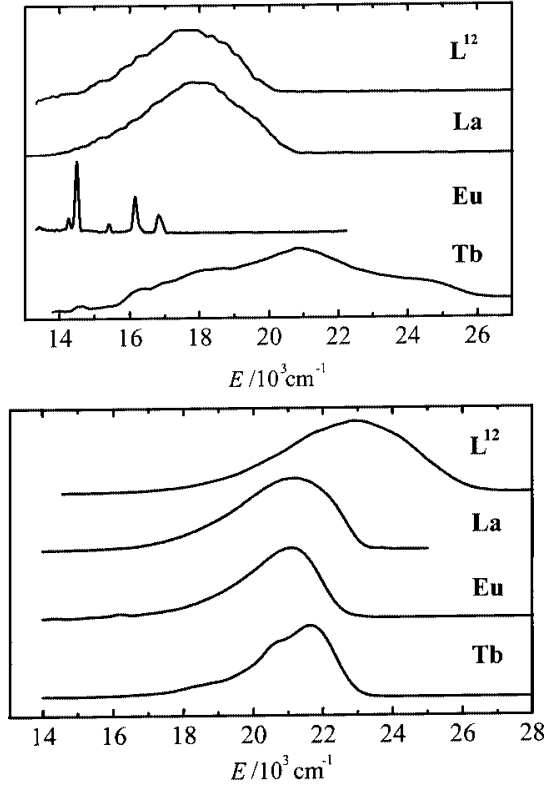

Figure 5. Top: Time-resolved emission spectra of $\mathbf{L}^{\mathbf{1 2}}$ and $\left[\mathrm{Ln}\left(\mathbf{L}^{\mathbf{1 2}}\right)_{3}\right]^{3+}$ in the solid state at $77 \mathrm{~K}$ and recorded with time delays of $0.01(\mathrm{Eu}), 0.1(\mathrm{~Tb})$ and $10 \mathrm{~ms}\left(\mathbf{L}^{\mathbf{1 2}}, \mathrm{La}\right)$. Bottom: Emission spectra of $\left[\mathbf{L n}\left(\mathbf{L}^{\mathbf{1 2}}\right)_{3}\right]^{3+}$ and $\mathbf{L}^{\mathbf{1 2}}\left(10^{-3} \mathrm{M}\right.$ in $\mathrm{MeCN}$ at $\left.293 \mathrm{~K}\right)$.

${ }^{3} \pi \pi^{*}$ state appears with a maximum around $17670 \mathrm{~cm}^{-1}$. The decay of the latter is a single exponential with a lifetime of $210 \pm 3 \mathrm{~ms}$, in the range of values previously reported for similar ligands $(160-323 \mathrm{~ms}) .^{[16,34]}$

The higher energy component observed in the electronic (or reflectance) spectrum of $\mathbf{L}^{\mathbf{1 2}}$ at $33950 \mathrm{~cm}^{-1}$ (33670 $\mathrm{cm}^{-1}$ ) is only slightly modified on complexation with $\mathrm{Ln}^{\mathrm{III}}$ ions, while the other band centred at $29590 \mathrm{~cm}^{-1}$ (27100 $\mathrm{cm}^{-1}$ ) undergoes an important red shift (Table 5, Figure 4). This observation reflects the electronic transformations associated with the trans-trans $\rightarrow$ cis-cis conformational change and the complexation of the lanthanide metal ions to the tridentate binding unit. ${ }^{[16,25,34]}$ On complexation of $\mathbf{L}^{\mathbf{1 2}}$ to $\mathrm{La}^{\mathrm{III}}$, the 0-phonon transitions of the singlet and triplet states are red-shifted by 1470 and $1170 \mathrm{~cm}^{-1}$, respectively (frozen $\mathrm{MeCN}$ solution, $77 \mathrm{~K}$, see Figure 5), and the ${ }^{3} \pi \pi^{*}$ lifetime decreases to $144 \pm 1 \mathrm{~ms}$. Emission from the ${ }^{1} \pi \pi^{*}$ state of the ligand is still visible for the Eu and $\mathrm{Tb}$ complexes, suggesting an incomplete intersystem crossing. Emission from the ${ }^{3} \pi \pi^{*}$ state disappears for the Eu solution, with a concomitant observation of the metal-centred emission bands. This is not the case for the $\mathrm{Tb}$ solution for which little or no ligand-to-Tb energy transfer takes place because the energy of the ligand donor level $\left(19750 \mathrm{~cm}^{-1}\right.$ in the La complex at $77 \mathrm{~K}$ ) is located below the metal ${ }^{5} \mathrm{D}_{4}$ acceptor level $\left(20350 \mathrm{~cm}^{-1}\right)$. Weak emission from the $\mathrm{Tb}^{\mathrm{III}}$ ion can only be seen on direct excitation of the metal states (Figure S3, Supporting Information), and the short and temperature-dependent $\mathrm{Tb}\left({ }^{5} \mathrm{D}_{4}\right)$ lifetime (decreasing from 0.38 to $0.12 \mathrm{~ms}$ between 13 and $55 \mathrm{~K}$ ) indicates that energy back transfer occurs in this complex.

In order to gain information on the chemical environment around the $\mathrm{Eu}^{\mathrm{III}}$ ion, we have measured the high-res- olution emission spectra of a solid state sample of $\left[\mathrm{Eu}\left(\mathbf{L}^{\mathbf{1 2}}\right)_{3}\right]\left(\mathrm{ClO}_{4}\right)_{3} \cdot 2 \mathrm{H}_{2} \mathrm{O}(\mathbf{8})$ at low temperature since this complex is only faintly luminescent at room temperature. The lifetime of the ${ }^{5} \mathrm{D}_{0}$ level, $0.85 \pm 0.01 \mathrm{~ms}$, is constant between 13 and $77 \mathrm{~K}$. This is shorter than the lifetimes reported for $\left[\mathrm{Eu}\left(\mathbf{L}^{\mathbf{1}}\right)_{3}\right]^{3+}(1.85 \mathrm{~ms} \text { in the range } 4-77 \mathrm{~K})^{[35]}$ and $\left[\mathrm{Eu}\left(\mathbf{L}^{11}\right)_{3}\right]^{3+}(2.03 \mathrm{~ms}$ at $10 \mathrm{~K}),{ }^{[36]}$ but similar to that found for $\left[\mathrm{Eu}\left(\mathrm{ClO}_{4}\right)_{2}\left(\mathrm{H}_{2} \mathrm{O}\right)\left(\mathbf{L}^{\mathbf{1 1}}\right)_{2}\right]^{+}(0.65 \mathrm{~ms}$ at $10 \mathrm{~K}) \cdot{ }^{[36]}$ Therefore, we cannot rule out the interaction of one water molecule in the first coordination sphere. The decrease in the $\mathrm{Eu}\left({ }^{5} \mathrm{D}_{0}\right)$ lifetime from $0.85 \mathrm{~ms}$ to $0.27 \mathrm{~ms}$ between 77 and $295 \mathrm{~K}$ indicates temperature-dependent quenching mechanisms, e.g. a ligand-to-metal charge transfer as demonstrated for $\left[\operatorname{Eu}\left(\mathbf{L}^{\mathbf{1}}\right)_{3}\right]^{3+},{ }^{[37,38]}$ and as reported for other $\mathrm{Eu}^{\mathrm{III}}$ complexes ${ }^{[39]}$ or other intermolecular interactions. In acetonitrile solution $\left(10^{-3} \mathrm{M}\right)$ at $295 \mathrm{~K}$, the lifetime is longer, reaching $0.96 \pm 0.01 \mathrm{~ms}$; since in addition to the hydration of $\mathbf{8}$ the solvent contains about $2 \mathrm{~mm} \mathrm{H}_{2} \mathrm{O}$, innersphere water interaction could occur. Using Horrocks equation, $q=1.05\left(k_{\mathrm{H} 2 \mathrm{O}}-k_{\mathrm{D} 2 \mathrm{O}}\right)^{[40]}$ and taking $k_{\mathrm{D} 2 \mathrm{O}}$ equal to $0.51 \mathrm{~ms}^{-1}$ (average of the values for the anhydrous tris species with $\mathbf{L}^{\mathbf{1}}$ and $\left.\mathbf{L}^{\mathbf{1 1}}\right),{ }^{[35,36]}$ we find $q=0.56$. This points to an equilibrium in solution between an anhydrous species and a monohydrate, as has been observed for triple helical complexes with terpyridine derivatives. ${ }^{[11]}$ Alternatively, it has been demonstrated that fast diffusing outer-sphere $\mathrm{H}_{2} \mathrm{O}$ molecules can contribute $0.25 \mathrm{~ms}^{-1}$ to the quenching of the $\mathrm{Eu}^{\mathrm{III}}$ ion in complexes with cyclen derivatives. ${ }^{[42]}$ Applying a similar correction for $\mathbf{8}$ results in a reduction of $q$ by approximately a factor of 2 . Therefore, given the uncertainties linked to this type of correlation, it is difficult to determine from the lifetime data whether or not a water molecule interacts in the inner coordination sphere. On the other hand, it is clear that the introduction of an electron-attracting group in the $\mathrm{R}^{3}$ position weakens the $\mathrm{Ln}-\mathrm{N}(\mathrm{py})$ bond, consistent with the relatively high energy of the ${ }^{5} \mathrm{D}_{0} \leftarrow{ }^{7} \mathrm{~F}_{0}$ transition $\left(17258 \mathrm{~cm}^{-1}\right.$ at $\left.295 \mathrm{~K}\right)$. Using the correlation proposed by Frey and Horrocks ${ }^{[43]}$ and the nephelauxetic parameter $\delta_{\mathrm{N}(\text { het })}=-15.3 \mathrm{~cm}^{-1}$ that we reported previously, ${ }^{[44]}$ we get $\delta_{\mathrm{N}(\mathrm{py})}=-8.1 \mathrm{~cm}^{-1}$, a value much lower than those proposed $\left(-12\right.$ to $\left.-17 \mathrm{~cm}^{-1}\right) .{ }^{[43,45]}$

The emission spectra recorded at $13 \mathrm{~K}$ on excitation through the ligand band, or direct laser excitation of the ${ }^{5} \mathrm{D}_{0} \leftarrow{ }^{7} \mathrm{~F}_{0}$ transition, display fairly broad bands which are compatible with a distorted $D_{3}$ symmetry environment for the metal ion (Figure S4). The relative intensities of the ${ }^{5} \mathrm{D}_{0}$ $\rightarrow{ }^{7} \mathrm{~F}_{J}$ transitions are $0.07,1.00,1.28,<0.01$ and 4.11 for $J=0,1,2,3$, and 4 , respectively. The ${ }^{5} \mathrm{D}_{0} \rightarrow{ }^{7} \mathrm{~F}_{1}$ transition displays two main components, one of them appearing as a doublet with a splitting of $17 \mathrm{~cm}^{-1}$, while the ${ }^{5} \mathrm{D}_{0} \rightarrow{ }^{7} \mathrm{~F}_{2}$ transition shows two doublets with a splitting of 13 and 14 $\mathrm{cm}^{-1}$, respectively. Finally, the ${ }^{5} \mathrm{D}_{0} \rightarrow{ }^{7} \mathrm{~F}_{4}$ transition displays four main components, three of them having a very weak intensity, again compatible with a distorted $D_{3}$ local symmetry.

To get a better insight into the various energy conversion processes occurring in the $\left[\operatorname{Ln}\left(\mathbf{L}^{\mathbf{1 2}}\right)_{3}\right]^{3+}$ complexes, we have determined the quantum yields of both the ligand- and 
metal-centred luminescence of $10^{-3} \mathrm{M}$ solutions at $295 \mathrm{~K}$, and the ratio between the integrated triplet and singlet state emissions, $I^{(\mathrm{T})} / I^{(\mathrm{S})}$ for the free ligand and its $\mathrm{La}^{\mathrm{III}}$ complex at $77 \mathrm{~K}$. The quantum yield of $\left[\mathrm{La}\left(\mathbf{L}^{\mathbf{1 2}}\right)_{3}\right]^{3+}\left(Q^{\mathrm{F}}=5.5 \%\right)$ decreases by a factor of 9 with respect to that of the free ligand $\left(Q^{\mathrm{F}}=51 \%\right)$, and the ligand-centred phosphorescence increases, as indicated by $I^{(\mathrm{T})} / I^{(\mathrm{S})}$ which increases from $8 \times 10^{-5}$ to $9.8 \times 10^{-3}$ on complexation of $\mathbf{L}^{\mathbf{1 2}}$ with $\mathrm{La}^{\mathrm{III}}$, that is by a factor of 122 . The better intersystem crossing (isc) efficiency in the $\mathrm{La}^{\mathrm{III}}$ complex may be explained by (i) the reduced energy gap between the ${ }^{1} \pi \pi^{*}$ and ${ }^{3} \pi \pi^{*}$ states: $2350 \mathrm{~cm}^{-1}$, determined from the energy of the 0 -phonon transitions, in contrast to $2650 \mathrm{~cm}^{-1}$ in the free ligand (Figure 6) and (ii) the spin-orbit mixing of the singlet and triplet states induced by the complexation with $\mathrm{La}^{\mathrm{III}} \cdot{ }^{[46]}$ The quantum yield of the metal-centred luminescence of $\left[\mathrm{Eu}\left(\mathbf{L}^{\mathbf{1 2}}\right)_{3}\right]^{3+}$ obtained on ligand excitation remains very small, $Q_{\mathrm{L}}^{\mathrm{Eu}}=5 \times 10^{-3} \%$, not only because the efficiency of the isc process stays small, but most probably because of photoinduced electron transfer processes, as already pointed out for the triple helical complex with $\mathbf{L}^{1}{ }^{[37,38]}$

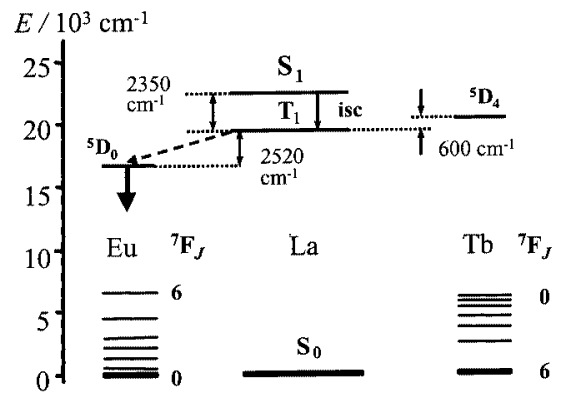

Figure 6. Schematic energy diagram for $\left[\operatorname{Ln}\left(\mathbf{L}^{\mathbf{1 2}}\right)_{3}\right]^{3+}$ complexes. Data for $S_{1}$ and $T_{1}$ are those of the La ${ }^{I I I}$ complex in the solid state at $77 \mathrm{~K}$ (0-phonon transitions).

\section{Conclusion}

The introduction of a chiral neopentyl ester group in the 4-position of the central pyridine ring of ligand $\mathbf{L}^{\mathbf{1}}$ to yield $\mathbf{L}^{\mathbf{1 2}}$ leads to the formation of thermodynamically stable 1:3 complexes with lanthanide ions in acetonitrile, as shown by the $\log K_{3}$ values in the range 2.9-4.6. Chiro-optical data clearly suggest the helical wrapping of the ligand strands around the $\mathrm{Ln}^{\mathrm{III}}$ ions. As a comparison, the bulky neopentyl groups grafted onto the benzimidazole side arms in $\mathbf{L}^{\mathbf{1 1}}$ precluded helical wrapping, a fact confirmed by the specific rotary dispersion measurements. ${ }^{[18]}$ Although only a small excess of one diastereoisomer is induced in solution by the chiral ligand $\mathbf{L}^{\mathbf{1 2}}$, as was observed for complexes with $\mathbf{L}^{*}$, [23] this work reveals that structural chirality may be induced in triple helical complexes by a suitable design of the ligand. The substitution also significantly modifies the photophysical properties of the tris complexes, compared with those with $\mathbf{L}^{11}{ }^{[36]}$ In particular, the ligand-to-metal energy transfer is amplified for $\mathrm{Eu}$, but cancelled for $\mathrm{Tb}$.

Therefore, this study demonstrates that, in addition to the electronic and photophysical properties which may be modulated by varying the substituent in the $\mathrm{R}^{3}$ position, a diastereomeric excess can be induced in solution if this substituent is chiral. The combination of these properties opens new perspectives for the design of lanthanide triple helical complexes acting as probes for chiral recognition.

\section{Experimental Section}

Solvents and Starting Materials: Acetonitrile, dichloromethane, chloroform, tetrahydrofuran, pyridine and triethylamine were purified in the usual way. ${ }^{[47]}$ Silica gel (Merck 60, 0.04-0.06 mm) was used for preparative column chromatography. Other products were purchased from Fluka AG (Buchs, Switzerland) or Merck and used without further purification. 2,4,6-pyridinetricarboxylic acid was prepared according to a literature procedure. ${ }^{[48]}$ Lanthanide perchlorates were obtained as described previously. ${ }^{[49]}$

Caution: Dry perchlorates and their complexes with aromatic amines may easily explode and should be handled in small quantities and with extreme caution. ${ }^{[50]}$

Spectroscopic and Analytical Measurements: Electronic spectra in the UV/Vis range were recorded at $293 \mathrm{~K}$ with a Perkin-Elmer Lambda 900 spectrometer and 1.0 and $0.1 \mathrm{~cm}$ quartz cells. Reflectance spectra were recorded on finely ground powders dispersed in $\mathrm{MgO}(5 \%)$, with $\mathrm{MgO}$ as the reference, on the same spectrometer equipped with a Labsphere PELA-1000 integration sphere. Specific rotary dispersion values were measured from $10^{-3} \mathrm{M}$ solutions in degassed anhydrous acetonitrile at $298 \mathrm{~K}$ with the help of a JASCO DIP-370 polarimeter (sodium D line). IR spectra were obtained from $\mathrm{KBr}$ pellets with a Mattson $\alpha$-Centauri FT-IR spectrometer. Pneumatically assisted electrospray (ESIMS) mass spectra were recorded from MeCN solutions on API III or API 3000 tandem mass spectrometers (PE Sciex) by infusion at $10 \mu \mathrm{L} \mathrm{min}{ }^{-1}$. The spectra were recorded under low up-front declustering or collision-induced dissociation (CID) conditions, typically $\Delta V=0-30 \mathrm{~V}$ between the orifice and the first quadrupole of the spectrometer. ${ }^{1} \mathrm{H},{ }^{13} \mathrm{C} \mathrm{NMR}$ spectra and 2-D experiments were recorded at $25{ }^{\circ} \mathrm{C}$ on Bruker AM-360 or Bruker AVANCE 400-DRX spectrometers. Chemical shifts are reported in parts per million with respect to TMS. Ligand excitation and emission spectra were recorded on a Perkin-Elmer LS-50B spectrometer equipped for low temperature (77 K) measurements. The experimental procedures for high resolution, laserexcited luminescence studies have been published previously. ${ }^{[51]}$ Emission spectra are corrected for the instrumental function. Quantum yields of the ligand-centred emission were measured relative to quinine sulfate in $0.05 \mathrm{M} \mathrm{H}_{2} \mathrm{SO}_{4}\left(A_{347}=0.05\right.$, absolute quantum yield: 0.546). ${ }^{[52]}$ Quantum yields of the metal-centred emission were determined as described previously ${ }^{[53]}$ at excitation wavelengths at which (i) the Lambert-Beer law is obeyed and (ii) the absorption of the reference $\left[\operatorname{Ln}(\text { terpy })_{3}\right]^{3+}$ closely matches that of the sample. CPL measurements were made on an instrument described previously, operating in a differential photon-counting mode. ${ }^{[33]}$ Elemental analyses were performed by Dr H. Eder (Microchemical Laboratory, University of Geneva).

Spectrophotometric Titrations: The electronic spectra in the UV/Vis range were recorded at $298 \mathrm{~K}$ from $10^{-4} \mathrm{M}$ solutions in acetonitrile containing $\mathrm{Et}_{4} \mathrm{NClO}_{4}(0.1 \mathrm{M})$ as the inert electrolyte with a Perkin-Elmer Lambda 7 spectrometer connected to an external computer and in quartz cells of $0.100 \mathrm{~cm}$ path length. Solutions were prepared in a thermostatted vessel (Metrohm 6.1418.220) and the titrant solution was added with an automated burette from $\mathrm{Me}$ - 
trohm (6.1569.150 or .210) fitted with an anti-diffusion device. In a typical experiment, $5-10 \mathrm{~cm}^{3}$ of $\mathbf{L}^{\mathbf{1 2}}$ were titrated with a solution of $\mathrm{Ln}^{\mathrm{III}}$ triflate $\left(10^{-4} \mathrm{M}\right)$ in acetonitrile. After each addition of 0.20 $\mathrm{cm}^{3}$ and a delay of $2 \mathrm{~min}$, the spectrum was measured and transferred to the computer. In some instances, reverse titrations, i.e. with $\mathbf{L}^{\mathbf{1 2}}$ as the titrating species, were also performed to confirm the values of the stability constants. All the experiments were conducted in a dry box and the water content of the solutions, measured at the end of the titration by the Karl Fischer method, was always $<30 \mathrm{ppm}$. Factor analysis and stability constant determinations were carried out with the program SPECFIT, version 2.10. ${ }^{[54]}$

Crystal Structure of $\mathbf{L}^{\mathbf{1 2}}$ : The pale yellowish, lathlike crystals were directly transferred from the mother liquor into a drop of Hostinert 216 oil kept at $210 \mathrm{~K}$. A specimen was selected and placed in a glass capillary. The data collection, at $170 \mathrm{~K}$, took place on a Stoe IPDS system equipped with Mo- $K_{\alpha}$ radiation (Table 1 ). The image plate - crystal distance was set to $80 \mathrm{~mm}$, and a $\varphi$ interval of $1^{\circ}$ was chosen. Two hundred images were then exposed for $20 \mathrm{~min}$ each. Inspection of the reciprocal space revealed that about three quarters of the diffraction spots could be accounted for by the cell given in Table 1. The integration was based on an effective mosaic spread of 0.012 and a profile between 11 and 21 pixels. A peak overlap of 2 pixels was tolerated in order to retain the maximum number of reflections. Nevertheless, over 2700 reflections were eliminated because of severe peak overlap. The intensities were corrected for Lorentz and polarisation effects. No absorption correction could be applied since the crystal was all but invisible in the frozen oil, but the absorption coefficient appeared to be small. The decay during the measurement was negligible. The structure was solved in the space group $P 22_{1} 2_{1} 2_{1}$ with the help of SIR 97. ${ }^{[5]}$ The oxygen and nitrogen atoms were refined anisotropically and the carbon and hydrogen atoms isotropically; the latter were allowed to ride on their associated carbon atoms. The refinement seems to favour the $S$ configuration for the chirality centre C24 for both molecules, as expected from the synthesis and the observed rotary dispersion, but the value of Flack's parameter $(2 \pm 2)$ is not conclusive. ${ }^{56]}$ CCDC-186842 contains the supplementary crystallographic data for this paper, which can be obtained free of charge at www.ccdc.cam.ac.uk/conts/retrieving.html [or from the Cambridge Crystallographic Data Centre, 12 Union Road, Cambridge CB2 1EZ, UK; fax: (internat) +44-1223/336-033; E-mail: deposit@ccdc.cam.ac.uk].

Preparation of the Ligand. ( \pm )-2-(1-Hydroxyethyl)-1-methylbenzimidazole (1): A mixture of $N$-Methyl-1,2-phenylenediamine $(0.93$ $\left.\mathrm{cm}^{3}, 8.18 \mathrm{mmol}\right)$ and $( \pm)$-2-hydroxypropionic acid $\left(0.91 \mathrm{~cm}^{3}\right.$, $12.21 \mathrm{mmol}$ ) was refluxed for $45 \mathrm{~min}$ in $4 \mathrm{~N}$ hydrochloric acid (10 $\mathrm{cm}^{3}$ ). After cooling, the mixture was neutralised to $\mathrm{pH}=7.1$ with $\mathrm{NH}_{4} \mathrm{OH}(25 \%)$. The resulting brown crude solid was filtered, washed with water and recrystallised from hot water to give $1.13 \mathrm{~g}$ of 1 (6.41 mmol, 78\%). M.p. $106-108{ }^{\circ} \mathrm{C} .{ }^{1} \mathrm{H}$ NMR $(360 \mathrm{MHz}$, $\left.\mathrm{CD}_{3} \mathrm{OD}\right): \delta=1.73\left(\mathrm{~d},{ }^{3} J=7.0 \mathrm{~Hz}, 3 \mathrm{H}\right), 3.94(\mathrm{~s}, 3 \mathrm{H}), 4.93(\mathrm{~s}, 1$ $\mathrm{H}), 5.20\left(\mathrm{q},{ }^{3} \mathrm{~J}=7.0 \mathrm{~Hz}, 1 \mathrm{H}\right), 7.25-7.34(\mathrm{~m}, 2 \mathrm{H}), 7.50(\mathrm{~m}, 1 \mathrm{H})$, $7.66(\mathrm{~m}, 1 \mathrm{H}) \mathrm{ppm} .{ }^{13} \mathrm{C} \mathrm{NMR}\left(360 \mathrm{MHz}, \mathrm{CD}_{3} \mathrm{OD}\right): \delta=21.65$, $30.67,64.15,110.79,119.59,123.33,124.06,137.37,142.35$, $157.45 \mathrm{ppm}$. IR $(\mathrm{KBr}): \tilde{v}=1105\left(v_{\mathrm{C}-\mathrm{OH}}\right) \mathrm{cm}^{-1}$. ESI-MS $(\mathrm{MeOH})$ : $m / z=177.2[\mathrm{~L}+\mathrm{H}]^{+}$.

2-Acetyl-1-methylbenzimidazole (2): A solution of chromium trioxide (494 mg, $4.94 \mathrm{mmol})$ in water $\left(3 \mathrm{~cm}^{3}\right)$ was added dropwise to a solution of $1(1.13 \mathrm{~g}, 6.41 \mathrm{mmol})$ in glacial acetic acid $\left(5 \mathrm{~cm}^{3}\right)$ at $90{ }^{\circ} \mathrm{C}$. The reaction mixture was heated at $100{ }^{\circ} \mathrm{C}$ for $10 \mathrm{~min}$ and poured into water $\left(60 \mathrm{~cm}^{3}\right)$. The resulting precipitate was extracted with dichloromethane $\left(3 \times 30 \mathrm{~cm}^{3}\right)$, and the combined extracts dried $\left(\mathrm{Na}_{2} \mathrm{SO}_{4}\right)$ and the solvents evaporated. The resulting crude solid was recrystallised from methanol to give $849 \mathrm{mg}$ of $\mathbf{2}$ $(4.87 \mathrm{mmol}, 76 \%)$ as white crystals. M.p. $72-74{ }^{\circ} \mathrm{C} .{ }^{1} \mathrm{H}$ NMR $\left(360 \mathrm{MHz}, \mathrm{CDCl}_{3}\right): \delta=2.83(\mathrm{~s}, 3 \mathrm{H}), 4.11(\mathrm{~s}, 3 \mathrm{H}), 7.33-7.37(\mathrm{~m}$, $1 \mathrm{H}), 7.41(\mathrm{~m}, 2 \mathrm{H}), 7.87(\mathrm{~m}, 1 \mathrm{H}) \mathrm{ppm} .{ }^{13} \mathrm{C} \mathrm{NMR}(360 \mathrm{MHz}$, $\left.\mathrm{CDCl}_{3}\right): \delta=28.18,32.38,110.64,122.02,123.82,126.06,137.07$, 141.71, 146.28, $193.46 \mathrm{ppm}$. IR (KBr): $\tilde{v}=1684\left(v_{\mathrm{CO}}\right) \mathrm{cm}^{-1}$. ESI$\operatorname{MS}(\mathrm{MeOH}): m / z=175.1[\mathrm{~L}+\mathrm{H}]^{+}$.

1-\{[(Methylbenzimidazol-2-yl)carbonyl]methyl\}-1-pyridinium Iodide (3): $2(211 \mathrm{mg}, 1.21 \mathrm{mmol})$ and $\mathrm{I}_{2}(307 \mathrm{mg}, 1.21 \mathrm{mmol})$ were dissolved in dry distilled pyridine $\left(4 \mathrm{~cm}^{3}\right)$ under an inert atmosphere. After $20 \mathrm{~min}$ at room temp., the mixture was heated at $100{ }^{\circ} \mathrm{C}$ for $15 \mathrm{~h}$, then cooled to room temperature. The resulting brown precipitate was filtered, washed once with pyridine/diethyl ether (1:1, 5 $\left.\mathrm{cm}^{3}\right)$ and twice with diethyl ether $\left(10 \mathrm{~cm}^{3}\right)$. The dried crude product was recrystallised from ethanol with charcoal to give $410 \mathrm{mg}$ of 3 $(1.08 \mathrm{mmol}, 89 \%)$ as dark yellow needles. M.p. $205-207{ }^{\circ} \mathrm{C} .{ }^{1} \mathrm{H}$ NMR (360 MHz, [D $]_{6}$ DMSO): $\delta=4.11(\mathrm{~s}, 3 \mathrm{H}), 6.54(\mathrm{~s}, 2 \mathrm{H}), 7.46$ $(\mathrm{m}, 1 \mathrm{H}), 7.56(\mathrm{~m}, 1 \mathrm{H}), 7.84(\mathrm{~m}, 1 \mathrm{H}), 7.94(\mathrm{~m}, 1 \mathrm{H}), 8.30(\mathrm{~m}, 2$ $\mathrm{H}), 8.76(\mathrm{~m}, 1 \mathrm{H}), 9.03(\mathrm{~m}, 2 \mathrm{H}) \mathrm{ppm} .{ }^{13} \mathrm{C} \mathrm{NMR}(360 \mathrm{MHz}$, $\left.\left[\mathrm{D}_{6}\right] \mathrm{DMSO}\right): \delta=31.96,66.56,111.86,121.22,124.22,126.47$, $127.74,136.65,141.07,143.47,145.56,146.46,184.43$ ppm. IR $(\mathrm{KBr}): \tilde{v}=1705\left(v_{\mathrm{CO}}\right) \mathrm{cm}^{-1}$. FAB-MS $(\mathrm{MeOH}): m / z=252.1[\mathrm{~L}$ $-\mathrm{I}]^{+}$.

4-(1-Methylbenzimidazol-2-yl)-4-oxobut-2-enoic Acid (4): Glyoxylic acid monohydrate $(1 \mathrm{~g}, 10.86 \mathrm{mmol})$, triethylamine $\left(1.52 \mathrm{~cm}^{3}\right.$, $10.86 \mathrm{mmol})$ and pyrrolidine $\left(0.33 \mathrm{~cm}^{3}, 3.8 \mathrm{mmol}\right)$ were sequentially added to a solution of $2(631 \mathrm{mg}, 3.62 \mathrm{mmol})$ in DMF (10 $\mathrm{cm}^{3}$ ). The mixture was stirred at room temp. for $48 \mathrm{~h}$ and $1 \%$ hydrochloric acid was then added until $\mathrm{pH}=1$. The solution was extracted with diethyl ether $\left(3 \times 20 \mathrm{~cm}^{3}\right)$ and the combined organic layers were dried $\left(\mathrm{Na}_{2} \mathrm{SO}_{4}\right)$ and the solvents evaporated. The resulting crude solid was redissolved with $10 \% \mathrm{NaHCO}_{3}\left(5 \mathrm{~cm}^{3}\right)$ to $\mathrm{pH}=8$ and washed with dichloromethane $\left(2 \times 10 \mathrm{~cm}^{3}\right)$. The aqueous phase was acidified to $\mathrm{pH}=1$ by addition of $10 \%$ hydrochloric acid and extracted with diethyl ether $\left(3 \times 10 \mathrm{~cm}^{3}\right)$. The combined organic layers were washed with water $\left(2 \times 30 \mathrm{~cm}^{3}\right)$, dried $\left(\mathrm{Na}_{2} \mathrm{SO}_{4}\right)$ and the solvents evaporated. The resulting crude solid was recrystallised by slow diffusion of hexane into an ethyl acetate solution to give $251 \mathrm{mg}$ of $4(1.09 \mathrm{mmol}, 30 \%)$ as brownish-red needles. M.p. $194-196{ }^{\circ} \mathrm{C} .{ }^{1} \mathrm{H}$ NMR $\left(360 \mathrm{MHz},\left[\mathrm{D}_{6}\right] \mathrm{DMSO}\right): \delta=$ $4.15(\mathrm{~s}, 3 \mathrm{H}), 6.83\left(\mathrm{~d},{ }^{3} J=15.9 \mathrm{~Hz}, 1 \mathrm{H}\right), 7.39(\mathrm{~m}, 1 \mathrm{H}), 7.50(\mathrm{~m}$, $1 \mathrm{H}), 7.75(\mathrm{~m}, 1 \mathrm{H}), 7.88(\mathrm{~m}, 1 \mathrm{H}), 8.28\left(\mathrm{~d},{ }^{3} \mathrm{~J}=15.9 \mathrm{~Hz}, 1 \mathrm{H}\right)$ ppm. ${ }^{13} \mathrm{C}$ NMR (360 MHz, [D $]$ DMSO): $\delta=32.18,111.64,121.45$, $123.85,126.32,132.46,136.65,137.03,141.22,146.17,166.24$, $181.66 \mathrm{ppm}$. IR $(\mathrm{KBr}): \tilde{v}=1707,1670\left(v_{\mathrm{CO}}\right) \mathrm{cm}^{-1}$. ESI-MS $(\mathrm{MeOH}): m / z=231.2[\mathrm{~L}+\mathrm{H}]^{+}$.

Ethyl 2,6-Bis[(1-methylbenzimidazol-2-yl)]pyridine-4-carboxylate (5): A mixture of 2,4,6-pyridinetricarboxylic acid (1 g, $4.7 \mathrm{mmol})$, freshly distilled thionyl chloride $\left(15 \mathrm{~cm}^{3}, 207 \mathrm{mmol}\right)$ and DMF $\left(0.12 \mathrm{~cm}^{3}\right)$ was refluxed for $90 \mathrm{~min}$ in dry dichloromethane (40 $\mathrm{cm}^{3}$ ), evaporated and dried under vacuum for $60 \mathrm{~min}$. The resulting solid was dissolved in dry dichloromethane $\left(45 \mathrm{~cm}^{3}\right)$, and a mixture of 2-nitro- $N$-ethylaniline $(1.08 \mathrm{~g}, 7.1 \mathrm{mmol})$ and triethylamine $(6.6$ $\left.\mathrm{cm}^{3}, 47 \mathrm{mmol}\right)$ in dry dichloromethane $\left(30 \mathrm{~cm}^{3}\right)$ was added dropwise under inert atmosphere. The solution was stirred for $2 \mathrm{~h}$ at room temperature, refluxed for $6 \mathrm{~h}$ and the solvents evaporated. The brown residue was partitioned between dichloromethane $(3 \times$ $\left.100 \mathrm{~cm}^{3}\right)$ and half-saturated aqueous $\mathrm{NH}_{4} \mathrm{Cl}$ solution $\left(100 \mathrm{~cm}^{3}\right)$. The combined organic phases were dried $\left(\mathrm{Na}_{2} \mathrm{SO}_{4}\right)$ and the solvents evaporated. The crude product was dissolved in a mixture of ethanol/water $\left(250: 55 \mathrm{~cm}^{3}\right)$, and freshly activated iron powder $(8 \mathrm{~g}$, 
$143 \mathrm{mmol})$ and $25 \%$ hydrochloric acid $\left(45.7 \mathrm{~cm}^{3}, 352 \mathrm{mmol}\right)$ were added. The solution was refluxed for $8 \mathrm{~h}$ under inert atmosphere. The excess of iron was filtered off, and the ethanol was distilled off under vacuum. Water was then added to bring the total volume to $100 \mathrm{~cm}^{3}$. The resulting solution was poured into dichloromethane $\left(150 \mathrm{~cm}^{3}\right) \cdot \mathrm{Na}_{2} \mathrm{H}_{2}$ edta $2 \mathrm{H}_{2} \mathrm{O}(84 \mathrm{~g}, 236 \mathrm{mmol})$ in $150 \mathrm{~cm}^{3}$ water was then added, and the resulting mixture was neutralised to $\mathrm{pH}=7$ with $5 \mathrm{M}$ aqueous potassium hydroxide; $30 \% \mathrm{H}_{2} \mathrm{O}_{2}\left(1 \mathrm{~cm}^{3}\right)$ was added and the $\mathrm{pH}$ adjusted to 8.3. After vigorous stirring for $30 \mathrm{~min}$, the organic layer was separated and the aqueous phase extracted with dichloromethane $\left(3 \times 150 \mathrm{~cm}^{3}\right)$. The combined organic phases were dried $\left(\mathrm{Na}_{2} \mathrm{SO}_{4}\right)$ and the solvents evaporated. The resulting crude solid was dissolved in dry dichloromethane (40 $\left.\mathrm{cm}^{3}\right)$, then freshly distilled thionyl chloride $\left(15 \mathrm{~cm}^{3}, 207 \mathrm{mmol}\right)$ and $\operatorname{DMF}\left(0.12 \mathrm{~cm}^{3}\right)$ were added. The mixture was refluxed for $90 \mathrm{~min}$, evaporated and dried under vacuum for $60 \mathrm{~min}$. The crude product was cooled to $0{ }^{\circ} \mathrm{C}$, then dry ethanol $\left(20 \mathrm{~cm}^{3}\right)$ was added dropwise. The resulting solution was allowed to stand at room temperature, stirred for $60 \mathrm{~min}$, evaporated and dried under vacuum for $60 \mathrm{~min}$. The residue was partitioned between dichloromethane $\left(3 \times 40 \mathrm{~cm}^{3}\right)$ and half-saturated aqueous $\mathrm{NH}_{4} \mathrm{Cl}$ solution $\left(40 \mathrm{~cm}^{3}\right)$. The combined organic phases were dried $\left(\mathrm{Na}_{2} \mathrm{SO}_{4}\right)$ and the solvents evaporated. The resulting brownish-red crude solid was purified by column chromatography (silica gel, $\mathrm{CH}_{2} \mathrm{Cl}_{2} / \mathrm{MeOH}, 100: 0 \rightarrow 99: 1$ ) to give $251 \mathrm{mg}$ of $5(0.61 \mathrm{mmol}, 13 \%) .{ }^{1} \mathrm{H} \mathrm{NMR}\left(400 \mathrm{MHz}, \mathrm{CDCl}_{3}\right)$ : $\delta=1.46\left(\mathrm{t},{ }^{3} J=7.0 \mathrm{~Hz}, 3 \mathrm{H}\right), 4.25(\mathrm{~s}, 6 \mathrm{H}), 4.49\left(\mathrm{q},{ }^{3} J=7.0 \mathrm{~Hz}\right.$, $2 \mathrm{H}), 7.39$ (m, $4 \mathrm{H}), 7.48$ (m, $2 \mathrm{H}), 7.91(\mathrm{~m}, 2 \mathrm{H}), 8.95(\mathrm{~s}, 2 \mathrm{H})$ ppm. ${ }^{13} \mathrm{C} \mathrm{NMR}\left(400 \mathrm{MHz}, \mathrm{CDCl}_{3}\right): \delta=14.97,33.24,62.89$, $110.69,121.05,123.78,124.66,125.26,137.91,141.03,143.36$, $150.32,151.33,164.85 \mathrm{ppm} . \mathrm{IR}(\mathrm{KBr}): \tilde{v}=1712\left(v_{\mathrm{CO}}\right), 1597,1562$ $\left(v_{\mathrm{C}=\mathrm{C}}\right) \mathrm{cm}^{-1}$. ESI-MS $(\mathrm{MeCN}): m / z=412.2[\mathrm{~L}+\mathrm{H}]^{+}$.

2,6-Bis[(1-methylbenzimidazol-2-yl)]pyridine-4-carboxylic Acid (6). Procedure A: 3 (410 mg, $1.08 \mathrm{mmol}), 4(226 \mathrm{mg}, 0.98 \mathrm{mmol})$ and ammonium acetate ( $3 \mathrm{~g}, 38.92 \mathrm{mmol})$ were dissolved in ethanol (25 $\mathrm{cm}^{3}$ ). The mixture was refluxed for $24 \mathrm{~h}$ under an inert atmosphere, and then slowly cooled to room temperature. The resulting white crystals were separated by filtration and recrystallised from hot methanol to give $230 \mathrm{mg}$ of $\mathbf{6}(0.60 \mathrm{mmol}, 55 \%)$. Procedure B: A solution of $5(251 \mathrm{mg}, 0.61 \mathrm{mmol})$ in a mixture of ethanol/water, 1:4 $\left(5: 20 \mathrm{~cm}^{3}\right)$ containing potassium hydroxide $(17 \mathrm{~g}, 303 \mathrm{mmol})$ was refluxed for $24 \mathrm{~h}$. Ethanol was distilled off and the aqueous phase acidified to $\mathrm{pH}=3$ with $25 \%$ hydrochloric acid. The resulting precipitate was filtered off and washed with water to give $218 \mathrm{mg}$ of $6(0.57 \mathrm{mmol}, 93 \%)$ as a white powder. M.p. $>260{ }^{\circ} \mathrm{C}$. ${ }^{1} \mathrm{H}$ NMR (360 MHz, [D $]$ DMSO): $\delta=4.37(\mathrm{~s}, 6 \mathrm{H}), 7.38-7.47$ $(\mathrm{m}, 4 \mathrm{H}), 7.78(\mathrm{~m}, 2 \mathrm{H}), 7.87(\mathrm{~m}, 2 \mathrm{H}), 8.81(\mathrm{~s}, 2 \mathrm{H}) \mathrm{ppm} .{ }^{13} \mathrm{C}$ NMR (360 MHz, [D $]$ DMSO): $\delta=36.51,114.78,123.45,126.27$, 127.10, 128.81, 141.06, 146.18, 146.70, 153.00, 154.41, 166.54 ppm. IR $(\mathrm{KBr}): \tilde{v}=1716\left(v_{\mathrm{CO}}\right), 1617,1560\left(v_{\mathrm{C}=\mathrm{C}}\right) \mathrm{cm}^{-1}$. ESI-MS $(\mathrm{MeCN}): m / z=384.2[\mathrm{~L}+\mathrm{H}]^{+}, 767.4[2 \mathrm{~L}+\mathrm{H}]^{+}$.

Neopentyl 2,6-Bis[(1-methylbenzimidazol-2-yl)]pyridine-4-carboxylate $\left(\mathbf{L}^{\mathbf{1 2}}\right)$ : A mixture of $\mathbf{6}$ (430 mg, $\left.1.12 \mathrm{mmol}\right)$, freshly distilled thionyl chloride $\left(3.62 \mathrm{~cm}^{3}, 50 \mathrm{mmol}\right)$ and DMF $\left(0.03 \mathrm{~cm}^{3}\right)$ was refluxed for $90 \mathrm{~min}$ in dry dichloromethane $\left(10 \mathrm{~cm}^{3}\right)$, evaporated and dried under vacuum for $60 \mathrm{~min}$. A solution of $(-)-(S)-2-$ methyl-1-butanol $\left(1.2 \mathrm{~cm}^{3}, 11.2 \mathrm{mmol}\right)$ dried on molecular sieves was added to the resulting crude solid. After stirring for $30 \mathrm{~min}$ at room temp., the resulting violet solution was evaporated and the residue was redissolved in $\mathrm{CHCl}_{3}\left(10 \mathrm{~cm}^{3}\right)$. The organic phase was washed with water $\left(3 \times 20 \mathrm{~cm}^{3}\right)$, then with half-saturated aqueous $\mathrm{NH}_{4} \mathrm{Cl}\left(20 \mathrm{~cm}^{3}\right)$, dried $\left(\mathrm{Na}_{2} \mathrm{SO}_{4}\right)$ and the mixture evaporated to dryness. The resulting crude solid was purified by column chroma- tography (silica gel, $\mathrm{CH}_{2} \mathrm{Cl}_{2} / \mathrm{MeOH}, 100: 0 \rightarrow$ 99:1) and recrystallised by slow diffusion of hexane into a dichloromethane solution to give $245 \mathrm{mg}$ of $\mathbf{L}^{\mathbf{1 2}}(0.54 \mathrm{mmol}, 48 \%)$ as white crystals. M.p. 186-188 ${ }^{\circ} \mathrm{C} .{ }^{1} \mathrm{H}$ NMR $\left(360 \mathrm{MHz}, \mathrm{CDCl}_{3}\right): \delta=0.97\left(\mathrm{t},{ }^{3} \mathrm{~J}=\right.$ $7.3 \mathrm{~Hz}, 3 \mathrm{H}), 1.04\left(\mathrm{~d},{ }^{3} J=6.8 \mathrm{~Hz}, 3 \mathrm{H}\right), 1.29\left(\mathrm{~m},{ }^{3} J=7.3 \mathrm{~Hz}, 1\right.$ $\left.\mathrm{H},{ }^{2} J=13.6 \mathrm{~Hz}\right), 1.56\left(\mathrm{~m},{ }^{3} J=7.3 \mathrm{~Hz}, 1 \mathrm{H},{ }^{2} J=13.6 \mathrm{~Hz}\right), 1.95$ (1 H, pseudo-oct., $\left.{ }^{3} J=6.3-7.3 \mathrm{~Hz}\right), 4.23\left(\mathrm{dd}, 1 \mathrm{H},{ }^{3} J=6.3 \mathrm{~Hz}\right)$, $4.24(\mathrm{~s}, 6 \mathrm{H}), 4.32\left(\mathrm{dd}, 1 \mathrm{H},{ }^{3} \mathrm{~J}=6.3 \mathrm{~Hz}\right), 7.35-7.43(\mathrm{~m}, 4 \mathrm{H}), 7.48$ $(\mathrm{m}, 2 \mathrm{H}), 7.90(\mathrm{~m}, 2 \mathrm{H}), 8.92(\mathrm{~s}, 2 \mathrm{H}) \mathrm{ppm} .{ }^{13} \mathrm{C} \mathrm{NMR}(360 \mathrm{MHz}$, $\left.\mathrm{CDCl}_{3}\right): \delta=11.35,16.59,26.20,32.68,34.34,70.96,110.15$, $120.60,123.20,124.10,124.68,137.35,140.51,142.79,149.78$, $150.79,164.44 \mathrm{ppm}$. IR $(\mathrm{KBr}): \tilde{v}=1730\left(v_{\mathrm{CO}}\right), 1587,1564\left(v_{\mathrm{C}=\mathrm{C}}\right)$ $\mathrm{cm}^{-1}$. ESI-MS (MeCN): $m / z=454.2[\mathrm{~L}+\mathrm{H}]^{+}$. $\mathrm{C}_{27} \mathrm{H}_{27} \mathrm{~N}_{5} \mathrm{O}_{2} \cdot 0.11 \mathrm{CH}_{2} \mathrm{Cl}_{2}$ : calcd. C 70.3, $\mathrm{H} \mathrm{5.9,} \mathrm{N} \mathrm{15.1;} \mathrm{found} \mathrm{C}$ 70.3, H 6.0, N 15.1.

Preparation of the Complexes: The 1:3 complexes $\left[\mathrm{Ln}\left(\mathbf{L}^{\mathbf{1 2}}\right)_{3}\right]\left(\mathrm{ClO}_{4}\right)_{3} \cdot x \mathrm{H}_{2} \mathrm{O}$ (La, $x=2,(7) ; \mathrm{Eu}, x=2,(8) ; \mathrm{Tb}, x=3$, (9)] were prepared by mixing $\mathbf{L}^{\mathbf{1 2}}$ with stoichiometric amounts of $\mathrm{Ln}\left(\mathrm{ClO}_{4}\right)_{3} \cdot n \mathrm{H}_{2} \mathrm{O}(\mathrm{Ln}=\mathrm{La}, \mathrm{Eu}, \mathrm{Tb}$ and $n=0.2-0.6)$ in dichloromethane/acetonitrile. The complexes may be crystallised in $70-80 \%$ yields by slow diffusion of tert-butyl methyl ether into an acetonitrile solution. $\left[\mathrm{C}_{81} \mathrm{H}_{81} \mathrm{~N}_{15} \mathrm{O}_{18} \mathrm{Cl}_{3} \mathrm{La} \cdot 2 \mathrm{H}_{2} \mathrm{O}\right.$ : found $\mathrm{C}$ 53.2, $\mathrm{H}$ 4.6, $\mathrm{N}$ 11.6, calcd. $\mathrm{C}$ 53.1, $\mathrm{H}$ 4.7, $\mathrm{N}$ 11.5; $\mathrm{C}_{81} \mathrm{H}_{81} \mathrm{~N}_{15} \mathrm{O}_{18} \mathrm{Cl}_{3} \mathrm{Eu} \cdot 2 \mathrm{H}_{2} \mathrm{O}$ : found $\mathrm{C} 52.5, \mathrm{H}$ 4.7, N 11.4, calcd. C 52.7, $\mathrm{H}$ 4.6, N 11.4; $\mathrm{C}_{81} \mathrm{H}_{81} \mathrm{~N}_{15} \mathrm{O}_{18} \mathrm{Cl}_{3} \mathrm{~Tb} \cdot 3 \mathrm{H}_{2} \mathrm{O}$ : found $\mathrm{C} 51.9, \mathrm{H}$ 4.5, N 11.1; calcd. C 52.0, H 4.7, N 11.2]. IR (KBr): $\tilde{v}=1736(\mathrm{La})$, $1735(\mathrm{Eu}), 1734(\mathrm{~Tb}),\left(v_{\mathrm{CO}}\right) ; 1593,1568(\mathrm{La}), 1591,1570(\mathrm{Eu})$, 1589, $1570(\mathrm{~Tb}),\left(v_{\mathrm{C}=\mathrm{C}}\right)$ and 1092, 625 (ionic $\left.\mathrm{ClO}_{4}^{-}\right) \mathrm{cm}^{-1}$.

\section{Acknowledgments}

This work is supported through grants from the Swiss National Science Foundation. We thank Prof. Pierre Vogel for the use of his polarimeter, Dr. Anne-Sophie Chauvin for her help in the ligand synthesis and the Fondation Herbette (Lausanne) for the gift of spectroscopic equipment.

[1] J.-C. G. Bünzli in Lanthanide Probes in Life, Chemical and Earth Sciences. Theory and Practice, (Eds.: J.-C. G. Bünzli, G. R. Choppin), Elsevier Science Publ. B. V., Amsterdam, 1989, Ch. 7, 219-293.

[2] C. H. Evans, Biochemistry of the Lanthanides, Plenum Press, New York, 1990.

[3] D. Parker, Coord. Chem. Rev. 2000, 205, 109-130.

[4] J.-C. G. Bünzli, C. Piguet in Encyclopedia of Materials: Science and Technology (Eds.: K. H. J. Buschow, R. W. Cahn, M. C. Flemings, B. Ilschner, E. J. Kramer, S. Mahajan), Elsevier Science Ltd, Oxford, 2001, 10, Ch. 1.10.4, 4465-4476.

[5] G. Mathis in Rare Earths, (Eds.: R. Saez Puche, P. Caro), Editorial Complutense, Madrid, 1998, 285-297.

[6] I. Hemmilä, T. Ståhlberg, P. Mottram, Bioanalytical Applications of Labelling Technologies, Wallac Oy, Turku, 1995.

${ }^{[7]}$ V. W. W. Yam, K. K. W. Lo, Coord. Chem. Rev. 1999, 184, $157-240$.

${ }^{[8]}$ D. J. Bornhop, D. S. Hubbard, M. P. Houlne, C. Adair, G. E. Kiefer, B. C. Pence, D. L. Morgan, Anal. Chem. 1999, 71, 2607-2615.

[9] G. E. Kiefer, L. Jackson, D. J. Bornhop, 1999, US patent $5,928,627$.

${ }^{[10]}$ A. E. Merbach, E. Toth, The chemistry of contrast agents in medical magnetic resonance imaging, Wiley, London, 2001.

${ }^{[11]}$ Z. J. Guo, P. J. Sadler, Angew. Chem. Intl. Ed. Engl. 1999, 38, $1513-1531$.

${ }^{[12]}$ M. Komiyama, N. Takeda, H. Shigekawa, Chem. Commun. 1999, 1443-1451. 
${ }^{[13]}$ G. Pratviel, J. Bernardou, B. Meunier, Adv. Inorg. Chem. 1998, $45,251-312$.

${ }^{[14]}$ J.-C. G. Bünzli in Rare Earths, (Eds.: R. Saez Puche, P. Caro), Editorial Complutense, Madrid, 1998, 223-259.

${ }^{[15]}$ C. Piguet, J.-C. G. Bünzli, Chem. Soc. Rev. 1999, 28, 347-358.

${ }^{[16]}$ C. Piguet, J.-C. G. Bünzli, G. Bernardinelli, C. G. Bochet, P. Froidevaux, J. Chem. Soc., Dalton Trans. 1995, 83-97.

${ }^{[17]}$ S. Petoud, J.-C. G. Bünzli, F. Renaud, C. Piguet, K. J. Schenk, G. Hopfgartner, Inorg. Chem. 1997, 36, 5750-5760.

${ }^{[18]}$ G. Muller, J.-C. G. Bünzli, K. J. Schenk, C. Piguet, G. Hopfgartner, Inorg. Chem. 2001, 40, 2642-2651.

${ }^{[19]}$ E. Huskowska, J. P. Riehl, Inorg. Chem. 1995, 34, 5615-5621.

${ }^{[20]}$ S. C. J. Meskers, H. P. J. M. Dekkers, J. Phys. Chem. A 2001, 105, 4589-4599.

${ }^{[21]}$ H. Tsukube, S. Shinoda, Chem. Rev. 2002, 102, 2389-2404.

${ }^{[22]}$ L. J. Govenlock, C. E. Mathieu, C. L. Maupin, D. Parker, J. P. Riehl, G. Siligardi, J. A. G. Williams, Chem. Commun. 1999, $1699-1700$.

${ }^{[23]}$ G. Muller, B. Schmidt, J. Jiricek, G. Hopfgartner, J. P. Riehl, J.-C. G. Bünzli, C. Piguet, J. Chem. Soc., Dalton Trans. 2001, $2655-2662$.

[24] C. Piguet, B. Bocquet, G. Hopfgartner, Helv. Chim. Acta 1994, 77, 931-942.

${ }^{[25]}$ C. G. Bochet, C. Piguet, A. F. Williams, Helv Chim. Acta 1993 , $76,372-384$.

${ }^{[26]}$ F. Kröhnke, Synthesis 1976, 1-24.

${ }^{[27]}$ F. Kröhnke, Angew. Chem. Intl. Ed. Engl. 1963, 2, 225-228.

${ }^{[28]}$ M. I. Ali, A. M. Abd-Elfattah, H. A. Hammouda, Z. Naturforsch., Teil B 1976, 31, 254-256.

${ }^{[29]}$ M. J. Melo, F. Pina, A. L. Macanita, E. C. Melo, C. Herrmann, R. Förster, H. Koch, H. Wamhoff, Z. Naturforsch., Teil B 1992 , 47, 1431-1437.

${ }^{[30]}$ F. Renaud, C. Piguet, G. Bernardinelli, J.-C. G. Bünzli, G. Hopfgartner, Chem. Eur. J. 1997, 3, 1660-1667.

${ }^{[31]}$ W. Schecher, MINEQL ${ }^{+}$version 2.1, MD Environmental Research Software, Edgewater, NY, 1991.

${ }^{[32]}$ E. R. Malinowski, D. G. Howery, Factor Analysis in Chemistry, John Wiley, New York, Chichester, Brisbane, Toronto, 1980

${ }^{[33]}$ J. P. Riehl, F. S. Richardson, Chem. Rev. 1986, 86, 1-18.

${ }^{\left[{ }^{34]}\right.}$ C. Piguet, A. F. Williams, G. Bernardinelli, E. Moret, J.-C. G. Bünzli, Helv. Chim. Acta 1992, 75, 1697-1717.

${ }^{[35]}$ C. Piguet, A. F. Williams, G. Bernardinelli, J.-C. G. Bünzli, Inorg. Chem. 1993, 32, 4139-4149.
[36] G. Muller, PhD. Dissertation, University of Lausanne, 2000.

[37] S. Petoud, J.-C. G. Bünzli, T. Glanzman, C. Piguet, Q. Xiang, R. P. Thummel, J. Lumin. 1999, 82, 69-79.

${ }^{[38]}$ F. R. Gonçalves e Silva, R. L. Longo, O. L. Malta, C. Piguet, J.-C. G. Bünzli, Phys. Chem. Chem. Phys 2000, 2, 5400-5403.

[39] J. Bartis, M. Dankova, J. J. Lessmann, Q. H. Luo, W. deW. Horrocks, Jr., L. C. Francesconi, Inorg. Chem. 1999, 38, $1042-1053$

${ }^{[40]}$ W. deW. Horrocks, Jr., D. R. Sudnick, Acc. Chem. Res. 1981, 14, 384-384.

[41] C. Mallet, R. P. Thummel, C. Hery, Inorg. Chim. Acta 1993, 210, 223-231

${ }^{[42]}$ A. Beeby, I. M. Clarkson, R. S. Dickins, S. Faulkner, D. Parker, L. Royle, A. S. de Sousa, J. A. G. Williams, M. Woods, J. Chem. Soc., Perkin Trans. 2 1999, 493-503.

${ }^{[43]}$ S. T. Frey, W. deW. Horrocks, Jr., Inorg. Chim. Acta 1995, $229,383-390$

[44] S. Petoud, J.-C. G. Bünzli, K. J. Schenk, C. Piguet, Inorg. Chem. 1997, 36, 1345-1353.

${ }^{[45]}$ M. Latva, J. Kankare, J. Coord. Chem. 1998, 43, 121-142.

${ }^{[46]}$ S. Tobita, M. Arakawa, I. Tanaka, J. Phys. Chem. 1985, 89, $5649-5654$

${ }^{[47]}$ D. D. Perrin, W. L. F. Armarego, Purification of Laboratory Chemicals, Pergamon Press, Oxford, 1988.

${ }^{[48]}$ L. Syper, K. Kloc, J. Mlochowski, Tetrahedron 1980, 36, $123-129$.

[49] J.-C. G. Bünzli, J.-R. Yersin, C. Mabillard, Inorg. Chem. 1982, $21,1471-1476$

${ }^{[50]}$ W. C. Wolsey, J. Chem. Educ. 1973, 50, A335-A337.

[51] N. Martin, J.-C. G. Bünzli, V. McKee, C. Piguet, G. Hopfgartner, Inorg. Chem. 1998, 37, 577-589.

${ }^{[52]}$ S. R. Meech, D. C. Phillips, J. Photochem. 1983, 23, 193-217.

[53] H.-R. Mürner, E. Chassat, R. P. Thummel, J.-C. G. Bünzli, J. Chem. Soc., Dalton Trans. 2000, 2809-2816.

${ }^{[54]}$ H. Gampp, M. Maeder, C. J. Meyer, A. D. Zuberbühler, Talanta $1985,23,1133-1139$.

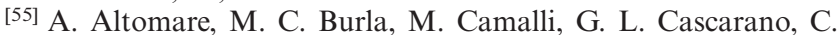
Giacovazzo, A. Guagliardi, G. G. Moliterni, G. Polidori, R. Spagna, J. Appl. Cryst. 1999, 32, 115-119.

${ }^{[56]}$ H. D. Flack, Acta Crystallogr., Sect. A 1983, 39, 876-881. H. D. Flack, G. Bernardinelli, J. Appl. Crystallogr., 2000, 33, $1143-1148$

Received June 3, 2002

[I02292] 